\title{
Familial Mediterranean Fever Present with Gastrointestinal Manifestations of Henoch Schonlein Purpura
}

\author{
Henoch Schönlein Purpurasının Gastrointestinal Tutulumuyla Seyreden \\ Ailevi Akdeniz Ateși Vakası
}

\author{
Fatih BATTAL ${ }^{1}$ (D), Yusuf GÜZEL ${ }^{1}$ (D), Nazan KAYMAZ¹ (D) $^{\text {Ezgi KIRMIZITAȘ }}{ }^{1}$ (D), Șenay KURTULUȘ ${ }^{2}$ \\ ${ }^{1}$ Çanakkale Onsekiz Mart University Faculty of Medicine Hospital Department of Pediatrics, Çanakkale, Turkey \\ ${ }^{2}$ Çanakkale Onsekiz Mart University Faculty of Medicine Hospital Department of Pediatrics Surgery, Çanakkale, Turkey
}

ORCID ID: Fatih Battal 0000-0001-9040-7880, Yusuf Güzel 0000-0002-1241-3561, Nazan Kaymaz 0000-0002-3962-4799,

Ezgi Kırmızıtaș 0000-0001-7941-799X, Șenay Kurtuluș 0000-0002-2178-2967

Cite this article as: Battal F et al. Familial Mediterranean Fever Present with Gastrointestinal Manifestations of Henoch Schonlein Purpura. Med J West Black Sea. 2021;5(2):309-313.

Corresponding Author

Fatih Battal

E-mail

battalfatih@hotmail.com
Received

03.03.2021

Revision

08.05.2021

Accepted

14.05.2021

\begin{abstract}
Henoch Schönlein Purpura is the most common small vessel vasculitis in childhood which is characterized with non-thrombocytopenic purpuric skin rash, arthritis, abdominal pain and renal disease. Palpable purpura usually occurs as the first clinical finding. However, gastrointestinal symptoms can rarely appear before the rash and may cause delays in diagnosis.

Here, we present a case of Henoch Schönlein Purpura who underwent appendectomy with the diagnosis of acute abdomen and developed skin involvement in clinical follow-up. Another important point of our case is; In the genetic analysis performed in our patient with Henoch Schönlein purpura attack, Familial Mediterranean Fever was diagnosed with heterozygous mutation M694V and V726A. Since Henoch Schönlein Purpura is more common in Familial Mediterranean Fever patients; Familial Mediterranean Fever findings should be questioned in patients with Henoch Schönlein Purpura and gene mutation analysis should be performed if Familial Mediterranean Fever findings are specified.
\end{abstract}

Keywords: Henoch Schonlein Purpura, Abdominal pain, Non-thrombocytopenic purpura, Familial Mediterranean Fever

\section{ÖZ}

Henoch Schönlein Purpurası artrit, karın ağıısı, non-trombositopenik purpura ve böbrek tutulumu ile seyreden, çocukluk çağında en sık görülen küçük damar vaskülitidir. Palpabl purpura genelde hastalığın ilk bulgusu olarak ortaya çıkar. Ancak gastrointestinal semptomlar nadiren döküntüden önce ortaya çıkarak tanıda gecikmelere neden olabilmektedir.

Bu yazıda akut batın kliniğiyle acil servisimize başvuran, apendektomi yapılan ve klinik takibi sırasında cilt tutulumunun ortaya çıkması ile Henoch Schönlein Purpurası tanısı alan bir vaka sunuyoruz. Vakamızın önemli olan bir diğer noktası da; Henoch Schönlein purpura atağı olan hastamızda yapılan genetik analizde M694V ve V726A heterozigot mutasyonu ile Ailevi Akdeniz Ateşi tanısı konmasıdır. Ailevi Akdeniz Ateşi hastalarında Henoch Schönlein Purpurası daha sık olduğu için; Henoch Schönlein Purpurası hastalarda Ailevi Akdeniz Ateşi bulguları sorgulanmalı ve Ailevi Akdeniz Ateşi bulguları belirtilmişse gen mutasyon analizi yapılmalıdır.

Anahtar Sözcükler: Henoch Schönlein Purpurası, Karın ağrısı, Non-trombositopenik purpura, Ailevi Akdeniz Ateşi 


\section{INTRODUCTION}

Henoch Schönlein Purpura (HSP) is a systemic vasculitis of childhood characterized by the accumulation of immune complexes containing immunoglobulin $A$ in small vessels histopathologically. HSP can affect many organ or systems including skin, joints, gastrointestinal system and kidneys. Palpable purpura usually occurs as the first finding. Gastrointestinal symptoms typically develop within eight days of the appearance of the rash, although much longer intervals (weeks to months) have been described (1). Although the first clinical symptom is generally non-thrombocytopenic purpura skin rash; gastrointestinal symptoms rarely precede the rash, as in our case.

Familial Mediterranean fever (FMF) is a hereditary autoinflammatory disorder characterized by recurrent bouts of fever and serosal inflammation. Diagnosis of FMF requires the presence of a confirmatory MEFV genotype and at least one of the following four clinical features: duration of one to three day episodes, arthritis, chest pain, or abdominal pain. Alternatively, in cases with no confirmatory MEFV genotype, the patient should have at least two of the above features. Confirmatory genotype means carriage of pathogenic or likely pathogenic mutations as homozygotes or compound heterozygotes (2).

Although there are many factors in the etiology of HSP, it is known that it is more common in Familial Mediterranean Fever patients (3). In this article, a case of HSP with gastrointestinal system involvement such as bloody diarrhea without severe abdominal pain and purpuric rash and then diagnosed with FMF by genetic analysis is presented.

\section{CASE REPORT}

A seven year-old male patient was admitted to the pediatric emergency service with symptoms of diffuse abdominal pain and vomiting. He had nonhemorrhagic diarrhea for two days. The patient had no recent history of infection or drug use, and no symptoms of fever or weight loss.

Vital signs of the patient were normal at the emergency service admission. The body weight was $20 \mathrm{~kg}(10-25 \mathrm{p})$ and height $120 \mathrm{~cm}$ (25-50p). Tenderness in the epigastric and right lower quadrant regions was detected on abdominal examination. Other system examinations were normal. It was learned that he has had intermittent abdominal pain in his history.

In laboratory tests; white blood cell count was $20200 / \mathrm{mm}^{3}$, hemoglobin $13.8 \mathrm{gr} / \mathrm{dL}$, hematocrit $39.5 \mathrm{gr} / \mathrm{dL}$, platelet count 529000/mm³, CRP $12.92 \mathrm{mg} / \mathrm{dL}$, calcium: $7.21 \mathrm{mg} / \mathrm{dL}$, chlorine $95 \mathrm{mmol} / \mathrm{L}$, total protein $5.89 \mathrm{gr} / \mathrm{dL}$, albumin 2.73 $\mathrm{gr} / \mathrm{dL}$, total bilirubin $0.3 \mathrm{mg} / \mathrm{dL}$, direct bilirubin $0.1 \mathrm{mg} / \mathrm{dL}$, APTT $30.3 \mathrm{sec}$, INR: 1.19. Hematuria and proteinuria were observed in urinalysis, with findings of +4 and +1 , respec- tively. No pathogen was found in the urine culture. Similarly, in the patient's stool culture, which also had no stool parasites, no pathogen was found. In the abdominal ultrasonography, edema of the intestinal loops and minimal free fluid in the retrovesical fossa was detected between the intestines. Accompanying, millimeter-sized multiple echogenic particles that did not give any level in the bladder were observed. He was hospitalized for diagnosis and treatment. Parenteral cefotaxime and amikacin were administered on suspicion of acute abdomen and pyelonephritis. During the follow-up of the patient, abdominal pain did not regress, and diarrhea continued. Bile vomiting also started. Multiple intraperitoneal lymphadenomegaly, diffuse free fluid in the abdomen, widespread thickness increase in the intestinal loops and focal dilated jejunal rings were observed on abdominal CT.

The patient had obvious signs of defense and rebound. He was operated. The appendix had ileal position and seemed to be acute appendicitis. All small intestines were edematous and distended, and the cecum was evaluated as normal (Figure 1). The clinical problems of the patient continued in the postoperative period. Shortly after; edema developed in the periorbital and dorsal surfaces of the patient's feet.

Laboratory tests revealed hyponatremia, hypocalcemia, hypopotasemia and hypoalbuminemia. Hematuria persisted at the same time. However the blood pressure of the patient was within the normal range, nephritic proteinuria $(16 \mathrm{mg} /$ $\mathrm{m}^{2} / \mathrm{hr}$ ) was detected with serum albumin level of $1.64 \mathrm{gr} /$ $\mathrm{dL}$. Additional laboratory tests aimed to detect etiology of hypoalbuminemia such anti-endomysium and anti-gliadine IgA antibodies were negative. Other tests evaluated were as follow and given with the results; fecal calprotectin value>300 $\mu \mathrm{g} / \mathrm{g}$ (upper limit $166 \mu \mathrm{g} / \mathrm{g}$ ), complement C3 65.5 mg/dL (79-152), complement C4 $17.5 \mathrm{mg} / \mathrm{dL}$ (16-38) and ASO $88.2 \mathrm{IU} / \mathrm{mL}(0-116)$.

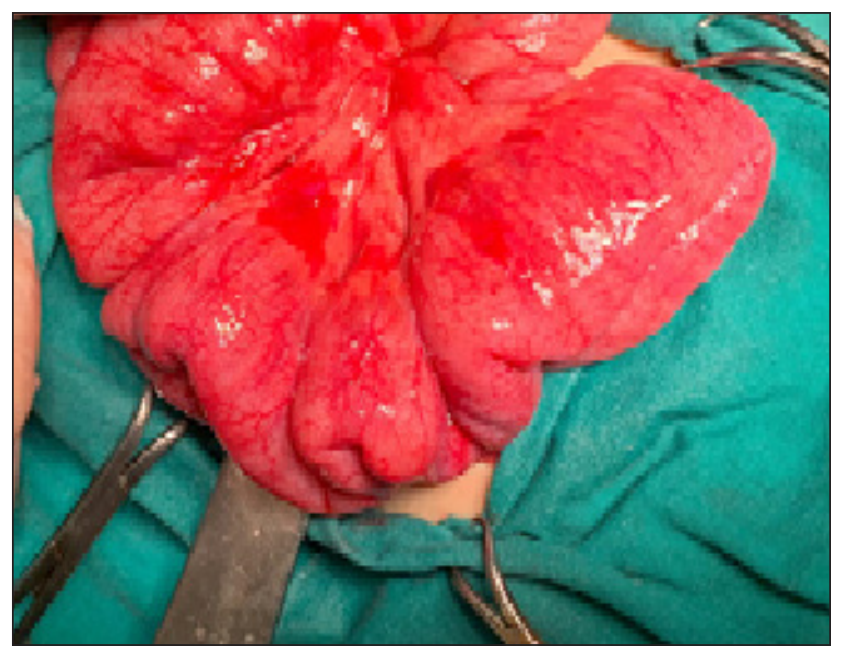

Figure 1: Oedematous and distended small intestines. 
Interestingly on the fifth day of his admission painless petechiae and palpable purpura lesions were observed in the periumbilical region and on the dorsomedial side of the left foot (Figure 2). Leukocytoclastic vasculitis was not observed in skin biopsy. It was reported as improving vasculitis. Methylprednisolone treatment was initiated in the patient diagnosed with HSP. Heterozygous mutations of M694V and V726A were detected when genetic evaluation was made for FMF due to a history of recurrent abdominal pain. Colchicine treatment was initiated in the patient diagnosed with FMF.

\section{CONCLUSION}

HSP is the most common childhood vasculitis that occurs particularly in children between 3-15 years of age. (4). Gastrointestinal symptoms typically develop within eight days of the appearance of the rash, although much longer intervals (weeks to months) have been described. Although the first clinical symptom is often non-thrombocytopenic purpura skin rash; gastrointestinal symptoms can rarely appear before the rash as the case presented.

According to diagnostic criteria determined by European League against Rheumatism/The Pediatric Rheumatology International Trials Organization/Pediatric Rheumatology European Society (EULAR/PRINTO/PRES) palpable purpura on the lower extremities is determined as the absolute criterion, and HSP could be diagnosed with at least one of the other four criteria (gastroinestinal system involvement, arthritis/arthralgia, renal involvement and histopathology (leukocytoclastic vasculitis or proliferative glomerulonephri-

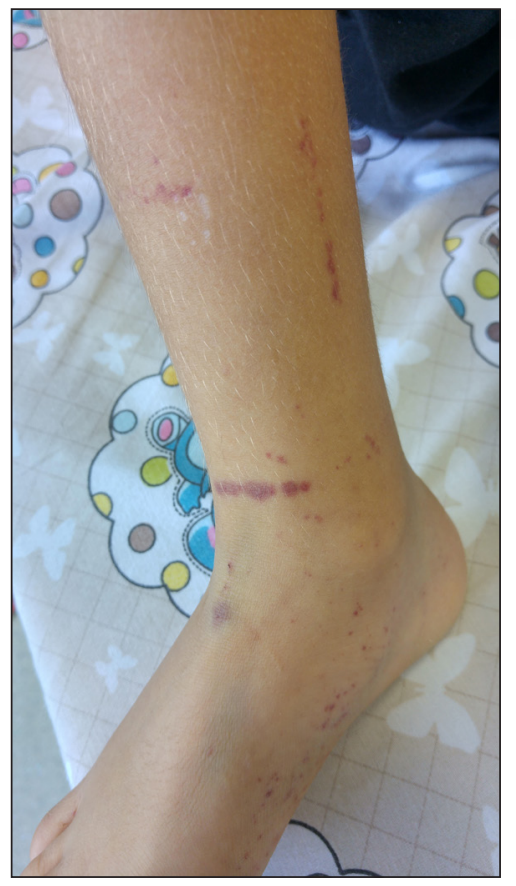

Figure 2: Palpabl purpura. tis) (5). Our patient had abdominal pain, diarrhea, nephritic syndrome, and palpable purpura that appeared later.

Gastrointestinal symptoms are observed in about $50 \%$ of children diagnosed with HSP (6). Mild symptoms such as nausea, vomiting, abdominal pain, paralytic ileus may be seen, as well as severe syptoms such as gastrointestinal bleeding, ischemia and necrosis, intussusception in the intestines may develop in gastrointestinal involvement of HSP. These signs are caused of peritoneal and visceral vasculitis causing extravasation of blood and interstitial fluid into the intestinal lumen. Gastrointestinal symptoms in HSP typically occur in the week following the appearance of purpura. However, in about 15 to 35 percent of cases, gastrointestinal symptoms precede the purpura (7). HSP cases in which rash emerged in the late period, such as 24 weeks after gastrointestinal symptoms, have also been described in the literature $(8,9)$. In our case, signs of gastrointestinal involvement were colic-like abdominal pain, along with the bloody diarrhea, nausea and vomiting that appeared before palpable purpura. Gastrointestinal involvement in HSP can also be observed with complications such as intestinal obstruction, invagination, intestinal perforation, pancreatitis, massive bowel necrosis and with acute apendicitis as observed in our case (6). Since vasculitis affecting the ileum and ascending colon in HSP resembles the clinical findings of acute appendicitis, it may cause unnecessary laparotomy.

On the other hand our case had also renal involvement of HSP which can be identified in 20 to 54 percent of patients with disease. Signs from isolated hematuria, moderate proteinuria, nephritic syndrome, nephrotic syndrome to renal failure can be observed (10). Renal failure did not develop in our patient with microscopic hematuria and proteinuria (16 $\mathrm{mg} / \mathrm{m}^{2} /$ hour). Kidney involvement may rarely be the first sign of the disease. If the first involvement in HSP is in an organ other than the skin, this may cause a delay in diagnosis.

The treatment of HSP is in the form of supportive therapy and generally proper diet, adequate hydration, analgesia and monitoring of vital findings are sufficient for supportive treatment (11). Steroids can also be used in the treatment of HSP. However, there is no consensus in the literature on this issue due to the low value of proof in the studies. However, the use of steroids is considered to be helpful in HSP patients with severe involvement of systems (12). The complaints of our patient completely regressed and he became fully recovered after $2 \mathrm{mg} / \mathrm{kg} /$ day methylprednisolone medication for 3 weeks.

In our case with a history of chronic abdominal pain, combined heterozygous mutations were found in M694V and $\mathrm{V} 726 \mathrm{~A}$ in the $10^{\text {th }}$ exon in the genetic analysis evaluated for FMF. In the literature the association of FMF and HSP 
has been reported as approximately 5\% (1). In a study of HSP patients with no diagnosis or clinical manifestations of FMF, MEFV gene mutations were detected in 43 percent of patients. (3). In an another research conducted with 168 HSP patients that questioned the presence of clinical signs of FMF, 10 patients had FMF symptoms in their anamnesis. MEFV gene mutations (M694V/-, V726A/- and E148Q/- heterozygous mutations) were detected in 3 of these patients (13). M694V homozygotes have a severe phenotype and are more likely to have arthritis, renal amyloidosis, erysipelas-like skin lesions, high fever, splenomegaly, and more frequent attacks as compared with individuals with other MEFV mutations (14). In another study, demonstrated that heterozygosity is not responsible for classical Mendelian FMF per se but constitutes a risk factor to develop FMF, with the risk six- to eightfold higher compared with noncarriers of MEFV mutation. The detection of two pathogenic mutations in the MEFV gene in an individual confirms the diagnosis (15). In our case, in which heterozygous M694V and V726A mutations were found, there were no symptoms except for intermittent attacks of abdominal pain.

In conclusion, since HSP is more frequent in FMF patients; FMF findings should be questioned in patients with HSP. If FMF findings are specified, gene mutation analysis should be performed. In addition FMF should be considered especially in patients operated with the diagnosis of appendicitis and whose complaints do not improve at postoperative process. Thus, the complications of FMF will be prevented by planning FMF treatment. On the other hand although skin involvement is commonly the first clinical sign in HSP, as in the case presented gastrointestinal involvement can be appear before skin involvement. It should be kept in mind that patients without skin involvement in HSP may have multisystemic involvement.

\section{Acknowledgment}

We thank to Prof. Dr. Fatma Sılan and Prof. Dr. Öztürk Özdemir from the medical genetics department for their contributions.

\section{Author Contrubitons}

Idea: Fatih Battal, Design: Fatih Battal, Yusuf Güzel, Check: Fatih Battal, Nazan Kaymaz, Data Collection and / or Processing: Yusuf Güzel, Ezgi Kırmızıtaş, Analysis- Interpretation: Fatih Battal, Yusuf Güzel, Literature Review: Yusuf Güzel, Writing: Fatih Battal, Yusuf Güzel, Nazan Kaymaz, Şenay Kurtuluş, Ezgi Kırmızıtaş, Critical Review: Fatih Battal, Nazan Kaymaz.

\section{Conflicts of Interest}

The authors declare that they have no conflict of interest.

\section{Financial Support}

This research did not receive any specific grant from funding agencies in the public, commercial, or not-for-profit sectors.

\section{Ethical Approval and Informed Consent}

Since it was a case report, ethics committee approval was not required. We asked the patient's parents to help us to publish the case report in an international journal for discussion, including disease symptoms, diagnosis, and image related content. They agreed us to use his medical records and signed the consent form. Legal permission has been obtained.

\section{Peer Review Process}

Extremely peer-reviewed.

\section{REFERENCES}

1. Bagga A, Dillon MJ. Leukocytoclastic vasculitis. In: Cassidy JT, Petty RE (eds). Textbook of Pediatric Rheumatology WB Saunders Company. Philadelphia, 2001: 569-79.

2. Shinar Y, Ceccherini I, Rowczenio D, Aksentijevich I, Arostegui $\mathrm{J}$, Ben-Chétrit E, Boursier G, Gattorno M, Hayrapetyan H, Ida $\mathrm{H}$, Kanazawa N, Lachmann HJ, Mensa-Vilaro A, Nishikomori R, Oberkanins C, Obici L, Ohara O, Ozen S, Sarkisian T, Sheils K, Wolstenholme N, Zonneveld-Huijssoon E, van Gijn ME, Touitou I. ISSAID/EMQN Best Practice Guidelines for the Genetic Diagnosis of Monogenic Autoinflammatory Diseases in the Next-Generation Sequencing Era. Clin Chem 2020;66(4):525.

3. Szer IS. Henoch-Schönlein purpura. Curr Opin Rheumatol 1994;6:25-31.

4. Chang WL, Yang YH, Lin YT, Chiang BL.Gastrointestinal manifestations in Henoch-Schönlein purpura: A review of 261 patients. Acta Paediatr 2004;93:1427.

5. Rozenbaum M, Rosner I. The clinicak features of FMF of elderly onset. Clin Exp Rheumatol 1984;12:347-348.

6. Feldth $\mathrm{RH}$, Stickler GB. The gastrointestinal manifestations of anaphylactoid purpura in children. Proc Staff Meet Mayo Clin 1962;37:465.

7. Ghrahani R, Ledika MA, Sapartini G, Setiabudiawan B. Age of onset as a risk factor of renal involvement in Henoch-Schönlein purpura. Asia Pac Allergy 2014;4(1):42-47.

8. Ardoin SP, Fels E. Vasculitis Syndromes. In: Kliegman RM, Stanton BF, Schor NF, St.Geme III JW, Behrman RE (eds). Nelson Textbook of Pediatrıcs, 19th ed. Philadelphia, Elsevier Saunders, 2011: 867-71.

9. Weiss PF, Feinstein JA, Luan X, Burnham JM, Feudtner C. Effects of corticosteroid on Henoch-Schönlein purpura: A systematic review. Pediatrics 2007;120(5):1079.

10. Acar B, Arıkan Y, Arıkan F, Dallar Y. System involvement evaluation of 168 case which is observed with henoch schönlein vasculitis in childhood. Ege Journal of Medicine 2010;49 (1): 7-12. 
11. Piram M, Mahr A. Epidemiology of immunoglobulin A vasculitis (Henoch-Schönlein): Current state of knowledge. Curr Opin Rheumatol 2013;25(2):171-178.

12. Ozen S, Pistorio A, lusan SM. EULAR/PRINTO/PRES criteria for Henoch-Schönlein purpura, childhood polyarteritis nodosa, childhood Wegener granulomatosis and childhood Takayasu arteritis: Ankara 2008. Part II: Final classification criteria. Ann Rheum Dis 2010;69(5):798.

13. Gunasekaran TS, Berman J, Gonzalez M. Duodenojejunitis: Is it idiopathic or is it Henoch-Schönlein purpura without the purpura? J Pediatr Gastroenterol Nutr 2000;30(1):22.
14. Grossman C, Kassel Y, Livneh A, Ben-Zvi I. Familial Mediterranean fever (FMF) phenotype in patients homozygous to the MEFV M694V mutation. Eur J Med Genet 2019; 62:103532.

15. Jéru I, Hentgen V, Cochet E, Duquesnoy P, Borgne GL, Grimprel E, Stojanovic KS, Karabina S, Grateau G, Amselem S. The risk of familial Mediterranean fever in MEFV heterozygotes: A statistical approach. PLoS One 2013;8:e68431. 


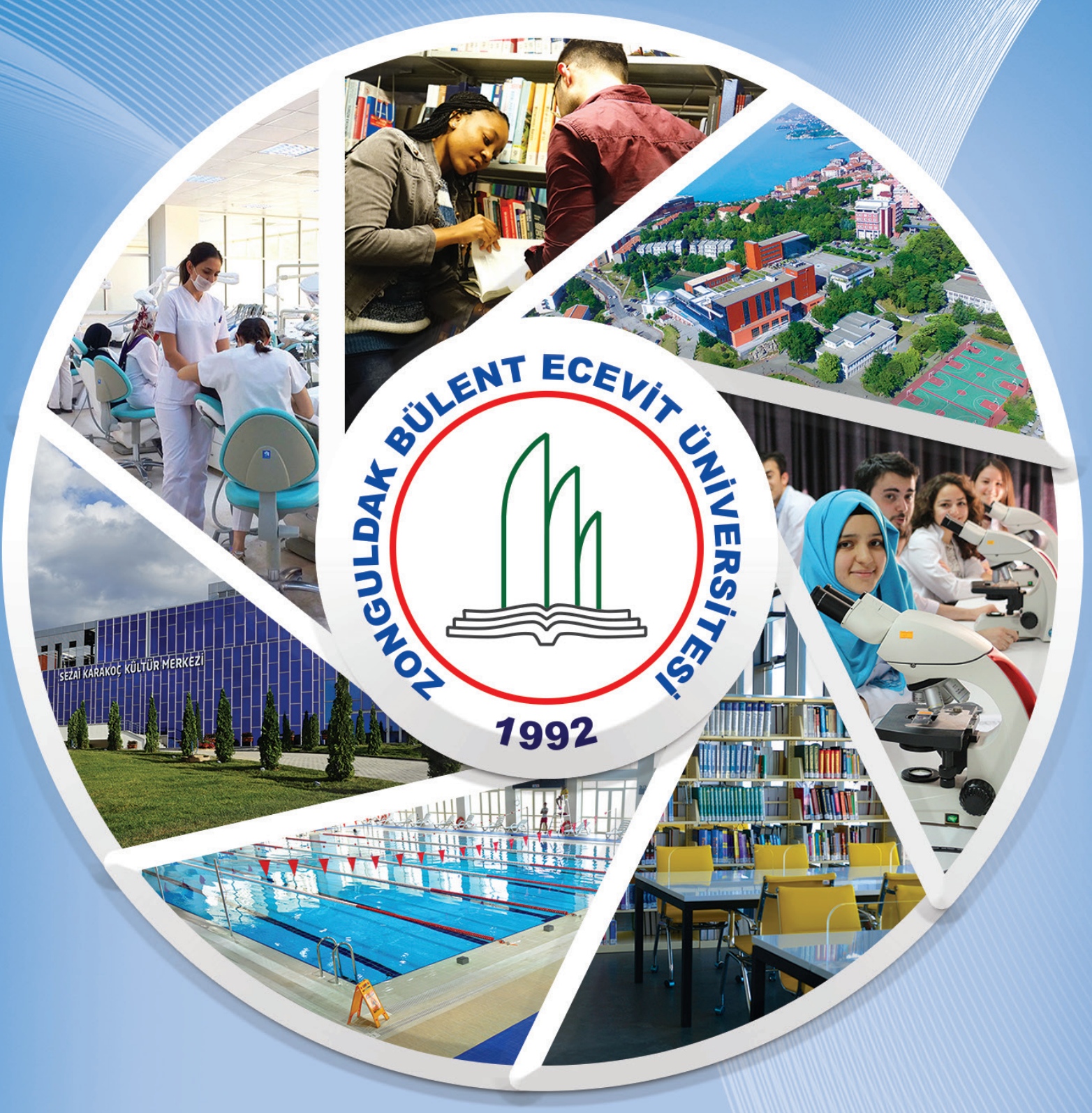

11 Farklı Kampüste

$\checkmark$ Çağdaş Eğitim Sınıfları

$\checkmark$ 7/24 Açık Kütüphaneler

$\checkmark$ Sosyal ve Kültürel Alanlar $\checkmark$ Tam Donanımlı Laboratuvarlar

- Modern Calıșma Salonları

$\checkmark$ Kafeler ve Yeșil Alanları ile

\section{Gelecek burada șekillenir...}

